\title{
PRZYCZYNY WYPADKÓW PRZY PRACY \\ ORAZ IDENTYFIKACJA DOLEGLIWOŚCI ZDROWOTNYCH ZWIĄZANYCH Z PRACĄ ZAWODOWĄ, W OPINII PRACOWNIKÓW POLSKICH PRZEDSIĘBIORSTW „MAŁEJ WIELKOŚCI"
}

\begin{abstract}
Streszczenie: W artykule przedstawiono wyniki badań przeprowadzonych wśród pracowników najmniejszych podmiotów gospodarczych w Polsce. Badania dotyczyły przyczyn wypadków przy pracy, które mają miejsce w badanych podmiotach gospodarczych oraz dolegliwości zdrowotnych związanych $\mathrm{z}$ wykonywaną pracą, jakie identyfikują u siebie respondenci. Wyniki przedstawiają tendencje w podjętym temacie oraz wskazują te obszary, które wymagają poprawy w aspekcie bezpieczeństwa i ochrony zdrowia pracowników przedsiębiorstw „małej wielkości”.
\end{abstract}

Słowa kluczowe: bezpieczeństwo pracy, ergonomia, ochrona zdrowia, prewencja, przedsiębiorstwa „małej wielkości”.

\section{Bezpieczeństwo pracy w polskich przedsiębiorstwach $w$ świetle raportów i doniesień - wprowadzenie}

Bezpieczeństwo i higiena pracy $\mathrm{w}$ przedsiębiorstwie jest tematem coraz większej ilości badań, które są realizowane przez instytucje i organizacje na całym świecie. Europejska Agencja Bezpieczeństwa i Ochrony Zdrowia w Pracy co jakiś czas prezentuje wyniki swoich badań, dotyczących bezpieczeństwa i ochrony zdrowia w różnych środowiskach pracy krajów europejskich.

W Polsce również realizowane są badania dotyczące warunków pracy, bezpieczeństwa i ochrony zdrowia, zagrożeń występujących w środowisku pracy, w tym stresu. Są one prowadzone przede wszystkim przez Państwową Inspekcję Pracy, Instytut Medycyny Pracy w Łodzi oraz Centralny Instytut Ochrony Pracy Państwowy Instytut Badawczy $\mathrm{w}$ Warszawie, które współpracują $\mathrm{z}$ firmami realizującymi zlecone badania oraz z Europejską Agencją Bezpieczeństwa i Zdrowia w Pracy.

Utrzymanie prawidłowego stanu bezpieczeństwa $\mathrm{w}$ zakładzie pracy jest istotnym elementem w aspekcie funkcjonowania całej firmy. Bardzo duży wpływ na bezpieczeństwo pracy mają warunki, jakie stwarza pracodawca swoim pracownikom w środowisku pracy. W świetle ogólnodostępnych raportów warunki pracy w polskich przedsiębiorstwach nie należą do najlepszych. Według raportu badania opinii pt. „Bezpieczeństwo Pracy w Polsce 2014 r.”, które zostało przeprowadzone przez

\footnotetext{
${ }^{1}$ Dr, Politechnika Częstochowska, marta.niciejewska@wz.pcz.pl
} 
instytut badawczy Millward Brown na reprezentatywnej grupie Polaków pracujących zawodowo. Dla $67 \%$ pracujących Polaków wiąże charakter swojej pracy z potencjalnym zagrożeniem dla życia lub zdrowia, z czego dla $9 \%$ respondentów jest to zagrożenie bardzo poważne. Zdaniem respondentów budownictwo i przemysł wydobywczy to branże obarczone największym ryzykiem utraty zdrowia lub życia. W świetle wyników co trzeci pracownik w ciągu ostatnich lat był świadkiem lub słyszał o wypadku w swoim miejscu pracy, z czego 7\% stanowiły wypadki śmiertelne. Co piąty pracownik był świadkiem rażących naruszeń przepisów BHP, dokonywanych zarówno przez pracodawcę, jak i jego pracowników. Szkolenia odbywają się w sposób regularny $\mathrm{w} 2 / 3$ przedsiębiorstw.

$\mathrm{Z}$ deklaracji respondentów wynika również, iż $\mathrm{W}$ większych przedsiębiorstwach bardziej niż w przedsiębiorstwach „małej wielkości” dba się o organizację i zakres szkoleń BHP. Pracownicy zatrudnieni przy produkcji, w służbie zdrowia, budownictwa oraz transporcie ocenili swoje miejsce pracy jako mniej bezpieczne niż osoby zatrudnione w handlu, usługach, szkolnictwie czy administracji państwowej. W świetle omawianego raportu respondenci za najpoważniejsze zagrożenia związane z pracą uważają wypadek samochodowy (branża transportowa), praca na wysokości (branża budowlana) oraz niebezpieczne maszyny (branża budowlana, produkcyjna). Tylko 13\% spośród badanych pracowników nie czuje się bezpiecznie w swoim miejscu pracy. Okazuje się, że ponad połowa pracowników bardziej ceni sobie poziom bezpieczeństwa w miejscu pracy, niż wysokość wynagrodzenia, które to ceni bardziej od bezpieczeństwa co ósmy respondent.

Zatem wśród dużej ilości pracowników objętych badaniem, bezpieczeństwo jest wartością autoteliczną, wartością samą w sobie, nie podlegającą żadnej wycenie. Podsumowując okazuje się, że wśród wielu elementów składających się na sprawne funkcjonowanie całego przedsiębiorstwa w aspekcie bezpieczeństwa pracy, szkolenia BHP są tym elementem, który należy zdecydowanie poprawić. Dość luźne podejście polskich pracowników do bezpieczeństwa zarówno materialnego jak i fizycznego powoduje, że nie są oni skłonni do planowania i zabezpieczania się przed przyszłymi zagrożeniami i ewentualnymi zdarzeniami wypadkowymi. Duży wskaźnik poczucia bezpieczeństwa wśród respondentów w miejscu pracy (aż 87\%) oraz przeświadczenie o tym, że są dobrze przeszkoleni ma się nijak do ilości wypadków, jak również ich przyczyn [1].

Z raportów Państwowej Inspekcji Pracy wyłania się niestety mniej optymistyczny obraz stanu bhp w polskich przedsiębiorstwach niż ten, prezentowany przez Koalicję Bezpieczni w Pracy. Otóż według badań przeprowadzonych przez Państwową Inspekcję Pracy w roku 2015 nadal w polskich przedsiębiorstwach mają miejsce negatywne zjawiska takie jak unikanie zatrudniania na podstawie umowy o pracę, nieterminowe wypłacanie wynagrodzeń, nierzetelne rozliczanie czasu pracy oraz brak odpowiedniej dbałości o bezpieczne i higieniczne warunki pracy. W świetle 
badań przeprowadzonych przez PIP w roku 2015 niezadowalający jest stan przestrzegania przepisów dotyczących szkolenia w dziedzinie bhp, czyli ważnego etapu pozyskiwania przez pracowników wiedzy o zagrożeniach dla zdrowia i życia występujących w zakładzie oraz działaniach ochronnych.

Okazuje się, że duża część kontrolowanych pracodawców nie zapewnia pracownikom przeszkolenia $\mathrm{w}$ zakresie bhp, zresztą sami pracodawcy również nie przechodzą takich szkoleń. Poza tym ocena ryzyka zawodowego, procedura oraz dokumentacja $\mathrm{w}$ kontrolowanych przedsiębiorstwach w świetle wyników prezentuje bardzo niski poziom. W ogólnej liczbie nieprawidłowości związanych z kolei z użytkowaniem maszyn i urządzeń technicznych mogących skutkować wypadkami przy pracy, aż $45 \%$ usunięto w trakcie kontroli w wyniku realizacji decyzji ustnych inspektorów. Należy dodać, iż podjęte działania nie wymagały żadnych dodatkowych nakładów pracy czy środków finansowych. Zatem opinie, które krążą wśród pracodawców, że aby zapewnić pracownikom bezpieczne warunki pracy potrzebne są duże nakłady finansowe, są nieprawdziwe.

Kontrola PIP dotyczyła również przedsiębiorstw budowlanych, w których ustalono mniej uchybień niż w latach ubiegłych. Takie zjawisko dotyczyło firm z wieloletnim doświadczeniem w branży budowlanej, które posiadały wykwalifikowane służby nadzoru a od podwykonawców egzekwowały przestrzegania przepisów. Negatywnym zjawiskiem zaobserwowanym w tych firmach jest zatrudnianie pracowników, którzy wcześniej nie mieli nic wspólnego z branżą budowlaną. W dodatku bardzo często są oni zatrudniani na podstawie innych form niż umowa o pracę. Podyktowane jest to szukaniem przez pracodawców oszczędności.

$\mathrm{W}$ innych przedsiębiorstwach - w świetle wyników raportu PIP - nie przestrzegane są przepisy i normy związane m.in. z pracą na wysokości, przenoszeniem i transportem ręcznym ciężarów. W nowo powstałych firmach z kolei brakuje instrukcji obsługi maszyn i urządzeń, instrukcji dotyczących wykonywania prac niebezpiecznych itp. Znacząca skalę nieprawidłowości stwierdzono w zakresie wyposażenia maszyn $\mathrm{w}$ odpowiednie osłony i urządzenia ochronne oraz elementy zabezpieczające przed dostępem pracownika do stref niebezpiecznych. W większości przedsiębiorstw poddanych kontroli inspektorzy wskazują na bardzo niepokojące zjawisko jakim jest zmniejszanie kosztów działalności podmiotów poprzez niewyposażanie pracowników w odzież i obuwie robocze. W części przedsiębiorstw zwłaszcza w podmiotach o charakterze leczniczym - nie ustalano okoliczności i przyczyn zgłaszanych przypadków zranień ostrymi narzędziami (np. medycznymi). Nieprzeprowadzanie postępowań powypadkowych wynikało przede wszystkim z obawy pracodawców o to, ze wzrost liczby poszkodowanych w wypadkach przy pracy spowoduje zwiększenie składki wypadkowej, co z kolei dodatkowo obciąży przedsiębiorstwo. Reasumując, jedną $\mathrm{z}$ głównych przyczyn nieprawidłowości 
w przedsiębiorstwach jest wciąż niedostateczny poziom wiedzy pracodawców o bezpieczeństwie i higienie pracy, szczególnie w małych zakładach, jak również tolerowanie odstępstw od podstawowych zasad bhp [2].

Jak podaje Rada Konsultacyjna powstała przy redakcji miesięcznika ATEST, warunki pracy w polskich przedsiębiorstw można ocenić jako „okolice stanów średnich". Największym problemem polskich przedsiębiorstw jest brak synergii między zmianami, które są przeprowadzane w przedsiębiorstwach a sposobem pracy pracowników. Przybywa bowiem w Polsce przedsiębiorstw, w których wdrażane są systemy zarządzania bezpieczeństwem ale bez należytej troski o zmianę nastawienia pracowników do własnego życia i zdrowia, ryzyka oraz przepisów bhp. Pomimo formalnego wdrożenia procedur zarządzania bezpieczeństwem, pracownicy pracują po staremu, a jedynym sposobem na obniżenie częstości wypadków pozostaje nadal ,zamiatanie ich pod dywan” [3].

Biorąc pod uwagę dane europejskie dotyczące stanu bezpieczeństwa i higieny pracy w przedsiębiorstwach, pracodawcy najczęściej uskarżają się na stres w pracy, ilość i tempo pracy, dolegliwości mięśniowo-szkieletowe wynikające przede wszystkim z nieergonomicznych stanowisk pracy oraz przenoszenie ciężkich przedmiotów i ładunków. Z bezpiecznych warunków w pracy najbardziej zadowoleni są Duńczycy i Holendrzy (ponad 80\% stwierdza, że są one na poziomie dobrym). Najniższy wskaźnik zadowolenia $\mathrm{z}$ warunków pracy na poziomie krajowym prezentują Grecy (tylko 16\% pracowników zadowolonych jest z warunków pracy). W Polsce natomiast 38\% pracowników deklaruje zadowolenie z warunków pracy [4].

Badania ponownie przeprowadzone wśród wybranych przedsiębiorstw w 2015 roku przez Koalicję Bezpieczni w Pracy poruszyło przede wszystkim kwestie związane $\mathrm{z}$ poczuciem bezpieczeństwa $\mathrm{w}$ miejscu pracy oraz używaniem środków ochrony indywidualnej. I choć z pozoru wyniki są zadowalające, to głębsza analiza nie jest optymistyczna. Pracownicy wciąż nie są świadomi potrzeby stosowania środków ochrony w swojej pracy. I tak np. aż 45\% pracowników branży produkcyjnej, energetycznej i górniczej zadeklarowało, że ich praca nie wymaga stosowania wspomnianych środków ochrony indywidualnej. Tylko co drugi badany deklaruje, że używa rękawic, odzieży ochronnej czy obuwia ochronnego.

Ten sam problem dotyczy przeprowadzonej przez respondentów oceny potencjalnego ryzyka w miejscu pracy. W 10-stopniowej skali (gdzie 10 oznacza brak zagrożeń dla zdrowia i życia) otrzymano wynik bliski 6,3. Specjaliści i eksperci nie upatrują w tym wysokim wyniku pozytywów. Nie jest to w ich odczuciu informacja o realnym poczuciu bezpieczeństwa, ale bardziej informacja o braku świadomości istnienia zagrożeń występujących w miejscu pracy [5]. 


\section{Przyczyny wypadków przy pracy i dolegliwości zdrowotne związane $\mathrm{z}$ pracą - badania wlasne}

W latach 2012-2015 autorka niniejszej pracy dokonała badania ankietowego polskich przedsiębiorstw „małej wielkości”, czyli podmiotów gospodarczych zatrudniających do 49 pracowników. Badanie dotyczyło szeroko pojętego bezpieczeństwa pracy. Kwestionariusz ankietowy zawierał m.in. pytania dotyczące przyczyn wypadków przy pracy oraz dolegliwości zdrowotnych związanych z pracą zawodową, a które respondenci identyfikują u siebie. Przebadanych zostało 1006 podmiotów gospodarczych. W wyniku przeprowadzonego badania ankietowego uzyskano odpowiedzi od podmiotów gospodarczych, według następującego rodzaju prowadzonej działalności - handlowej ( $4 \%$ z badanej grupy podmiotów gospodarczych), mieszanej ( $14 \% \mathrm{z}$ badanej grupy podmiotów gospodarczych), produkcyjnej ( $24 \%$ z badanej grupy podmiotów gospodarczych) oraz usługowej (58\% $\mathrm{z}$ badanej grupy podmiotów gospodarczych).

Najwięcej zatem kwestionariuszy ankietowych uzyskano z przedsiębiorstw usługowych. Prawie co piąty respondent, który wypełniał kwestionariusz ankietowy odpowiadając na pytania dotyczące wybranych kwestii bezpieczeństwa i higieny pracy, to pracownik w przedziale wieku 22-34 lata. Największą grupę respondentów stanowili pracownicy w przedziale wieku 35-44 lata. W badaniu wzięło udział tylko 7\% najmłodszych pracowników (18-24 lata) i 3,6\% najstarszych pracowników (56-64 lat oraz 65 lat i więcej). Co trzeci pracownik, który dokonał odpowiedzi na pytania zawarte $\mathrm{w}$ kwestionariuszu ankietowym był w przedziale wiekowym 45-54 lata. Zdecydowanie większą część respondentów stanowili ludzie „młodzi”. Największa liczba respondentów, która odpowiedziała na zadane pytania w kwestionariuszu ankietowym to pracownicy ze stażem pracy 6-10 lat ( prawie co trzeci respondent). Najmniej liczną grupą respondentów stanowili pracownicy z największym stażem pracy (16-20 lat - 2,5\%, 21-25 lat - 1,5\% oraz 26 lat i więcej - 1,4\%). Można powiedzieć, że zdecydowanie większą liczbę respondentów stanowili pracownicy o niskim stażu pracy (do 10 lat stażu pracy).

Dominującym rodzajem wykonywanej pracy wśród badanych respondentów była praca fizyczna (78\%). Pracę umysłową lub mieszaną wykonywał co 10 respondent. Wśród ankietowanych dominowali pracownicy o wykształceniu średnim (41\%) oraz zawodowym (36\%). Wykształcenie wyższe posiadał co piąty respondent. Podstawowe wykształcenie posiadał tylko $1 \%$ badanych pracowników. Większość respondentów stanowili mężczyźni (aż 72\%). Respondenci, którzy posiadali dodatkowe wykształcenie związane $\mathrm{z}$ bezpieczeństwem i higieną pracy stanowili zaledwie $7 \%$ badanych. Praca respondentów była raczej zespołowa, tylko co 4 respondent. Każdy podmiot gospodarczy, z którego autor pracy otrzymał kompletny 
kwestionariusza ankietowy, był wypełniany przez jednego respondenta. Liczba respondentów równa jest liczbie przebadanych najmniejszych podmiotów gospodarczych, czyli przedsiębiorstw „małej wielkości” - mikro- (1-9 pracowników) oraz małych przedsiębiorstw (10-49 pracowników).

\subsection{Przyczyny wypadków przy pracy w polskich przedsiębiorstwach „małej wielkości”}

Wypadek utożsamiany jest $\mathrm{z}$ wydarzeniem nagłym, którego nie można przewidzieć i który powoduje obrażenia u ludzi oraz straty materialne. Oczywiste zatem jest, iż wypadki nie są zdarzeniami pożądanymi i planowanymi. Do najczęstszych skutków wypadków zalicza się urazy i straty materialne. Przyczyny mogą z kolei być różne - od akceptowania zagrożeń, poprzez nieostrożne bądź błędne zachowania, po nieodpowiednie zarządzanie bezpieczeństwem. Oczywiście wypadki przy pracy stanowią niewielki procent wszystkich wypadków do jakich dochodzi, jednak obwarowane są dość dużym zbiorem norm, przepisów, procedur i rozporządzeń [6].

Podczas badań przeprowadzonych przez autorkę niniejszej pracy, respondenci musieli wskazać, które z podanych wydarzeń najczęściej powodują wypadki przy pracy - m.in. upadek, przygniecenie, zderzenie z ostrymi przedmiotami czy też porażenie prądem. Spośród wydarzeń powodujących wypadki najwyższą ocenę wskazań (średnio) otrzymały upadek i potknięcia $(3,478)$, uderzenie o nieruchomy przedmiot $(3,373)$ oraz zderzenie z ostrymi przedmiotami $(3,210)$. Za najbardziej niebezpieczne zarówno w sektorze przedsiębiorstw produkcyjnych, jak i usługowych były uznawane potknięcia, przy czym w tym drugim ocena ta była istotnie wyższa $(\mathrm{Z}=-4,524, \mathrm{p}<0,001)$. W sektorze usługowym wydarzenia powodujące wypadki oceniany były jako bardziej istotne niż w sektorze produkcyjnym $\mathrm{w}$ przypadku przygnieceń $(Z=-4,303, \mathrm{p}<0,001)$, uderzeń o nieruchomy przedmiot $(\mathrm{Z}=-5,818, \mathrm{p}<0,001)$ i pożar, wybuchy $(\mathrm{Z}=-2,882, \mathrm{p}=$ $0,004)$. W dalszej kolejności dokonano oceny rozkładu wskazań przyczyn wypadków przy pracy, występujących najczęściej w opinii respondentów, według sektora działalności (tab. 1).

Ponad połowa respondentów uznała, że każda $\mathrm{z}$ wymienionych przyczyn wypadków jest bardzo istotną. W ujęciu ogólnym najwyżej oceniono techniczne bezpieczeństwo pracy $(3,999)$, w przedsiębiorstwach produkcyjnych wyżej oceniono czynnik ludzki $(4,307)$ jako powód zagrożeń, istotnie wyżej niż w sektorze usługowym $(Z=7,232, p<0,001)$. Jeśli chodzi o różnice, sektor produkcyjny również wyżej od sektora usługowego ocenił możliwość spowodowania wypadku w wyniku (niewłaściwej) organizacji pracy $(Z=2,883, p=0,004)$. 
Tab. 1. Rozklad wskazań (wedtug średnich) przyczyn wypadków przy pracy występujących najczęściej w opinii respondentów wedlug sektora dzialalności

\begin{tabular}{|c|c|c|c|c|c|}
\hline ZMIENNA & \multicolumn{5}{|c|}{ ŚREDNIA OCENA } \\
\cline { 2 - 6 } & $\begin{array}{c}\text { Przedsiębiorstwa } \\
\text { produkcyjne }\end{array}$ & $\begin{array}{c}\text { Przedsiębiorstwa } \\
\text { usługowe }\end{array}$ & $\begin{array}{c}\text { Przedsiębiorstwa } \\
\text { handlowe }\end{array}$ & $\begin{array}{c}\text { Przedsiębiorstwa } \\
\text { mieszane }\end{array}$ & Razem \\
\hline $\begin{array}{c}\text { Techniczne } \\
\text { bezpieczeństwo } \\
\text { pracy (T) }\end{array}$ & 4,091 & 4,046 & 3,444 & 3,786 & 3,999 \\
\hline $\begin{array}{c}\text { Organizacja } \\
\text { pracy (O) }\end{array}$ & 3,979 & 3,803 & 3,556 & 3,707 & 3,823 \\
\hline $\begin{array}{c}\text { Czynnik ludzki } \\
\text { (L) }\end{array}$ & 4,307 & 3,806 & 3,667 & 4,043 & 3,954 \\
\hline
\end{tabular}

Źródło: Opracowanie własne - wartości istotne statystycznie na poziomie $\alpha=0,05$

\subsection{Dolegliwości zdrowotne związane $\mathrm{z}$ wykonywaną pracą w przedsiębiorstwach „małej wielkości”}

Za chorobę zawodową uznaje się schorzenie spowodowane działaniem czynników szkodliwych dla zdrowia, które występują w środowisku pracy. Przyczyną choroby zawodowej może być także sposób wykonywania pracy. Rozporządzenie Rady Ministrów z dnia 30 czerwca 2009 r. w sprawie chorób zawodowych (Dz. U. nr 105 poz. 869) reguluje aktualny wykaz wszystkich chorób zawodowych. Według tych danych za najliczniejszą grupę chorób zawodowych w roku 2015 zostały uznane choroby zakaźne lub pasożytnicze. Zaraz za nimi uplasowały się pylice płuc oraz przewlekłe choroby narządu głosu. Należy zauważyć, że przewlekłe choroby układu nerwowego oraz przewlekłe choroby układu ruchu to choroby coraz częściej zgłaszane przez orzeczników. Przeprowadzone badania ankietowe w przedsiębiorstwach „małej wielkości” pozwoliły wyodrębnić dolegliwości zdrowotne, na które skarżą się respondenci. Mogą choć nie muszą być one zaczątkiem chorób zawodowych. Na pewno wpływają negatywnie na wykonywanie pracy jak i samopoczucie poza nią.

Tabela 2 zawiera wyniki dotyczące rozkładu wskazań skutków uciążliwych warunków pracy, jakie występują najczęściej w opinii respondentów, według sektora działalności.

Respondenci nie wskazywali na wysoką istotność skutków uciążliwych warunków pracy. Maksymalna średnia ocena wynosiła 3,145 dla dolegliwości układu mięśniowo-szkieletowego. W każdym z przypadków oceny dla sektora przedsiębiorstw produkcyjnych były wyższe od ocen sektora usługowego. Istotne różnice dostrzeżono dla ocen dolegliwości układu mięśniowo - szkieletowego 
$\overline{(Z=2,252, p=0,024) \text {, objawów chronicznego zmęczenia }(Z=7,358, p<0,001)}$ i wypalenia zawodowego $(Z=5,103, p<0,001)$. Zmęczenie fizyczne towarzyszące sektorowi produkcyjnemu powoduje powstanie wyższych ocen w tym aspekcie. Z kolei często wykonywana monotonna praca (nierzadko przy taśmie) hamuje kreatywność i w dłuższym czasie powoduje wypalenie zawodowe.

Tab. 2. Rozklad wskazań (wedtug średnich) skutków uciążliwych warunków pracy występujących najczęściej w opinii respondentów wedtug sektora działalności

\begin{tabular}{|l|l|l|l|l|l|}
\hline \multirow{2}{*}{ ZMIENNA } & \multicolumn{5}{|c|}{ ŚREDNA OCENA } \\
\cline { 2 - 6 } & $\begin{array}{l}\text { Przedsiębiorstwa } \\
\text { produkcyjne }\end{array}$ & $\begin{array}{l}\text { Przedsiębiorstwa } \\
\text { usługowe }\end{array}$ & $\begin{array}{l}\text { Przedsiębiorstwa } \\
\text { handlowe }\end{array}$ & $\begin{array}{l}\text { Przedsiębiorstwa } \\
\text { mieszane }\end{array}$ & Razem \\
\hline $\begin{array}{l}\text { Dolegliwości } \\
\text { mięśniowo- } \\
\text { szkieletowe }\end{array}$ & 3,207 & 3,132 & 3,000 & 3,129 & 3,145 \\
\hline $\begin{array}{l}\text { Objawy } \\
\text { chronicznego } \\
\text { zmęczenia }\end{array}$ & 2,751 & 2,368 & 2,778 & 2,621 & 2,510 \\
\hline $\begin{array}{l}\text { Objawy } \\
\text { wypalenia } \\
\text { zawodowego }\end{array}$ & 2,390 & 2,178 & 2,500 & 2,293 & 2,256 \\
\hline $\begin{array}{l}\text { Objawy } \\
\text { choroby } \\
\text { układu } \\
\text { krążenia }\end{array}$ & 2,212 & 2,156 & 2,250 & 2,250 & 2,186 \\
\hline
\end{tabular}

Źródło: Opracowanie własne - wartości istotne statystycznie na poziomie $\alpha=0,05$

W tabeli 3 zostały zaprezentowane wyniki dotyczące rozkładu wskazań powodów dolegliwości układu mięśniowo-szkieletowego, występujących najczęściej w opinii respondentów według sektora działalności.

Respondenci nie wskazali bardzo istotnych powodów dolegliwości układu mięśniowo-szkieletowego. Jako istotne wskazano wyraźnie częściej w sektorze przedsiębiorstw produkcyjnych na często powtarzające się czynności $(Z=3,621, p<$ $0,001)$, nieergonomiczne stanowiska pracy $(Z=3,115, p<0,001)$ i wymuszoną pozycję pracy $(Z=1,977, \mathrm{p}=0,048)$. Wyżej ocenionym przez pracowników sektora przedsiębiorstw usługowych był ręczny transport materiałów. $(Z=-4,336, p<0,001)$. Od razu w oczy rzuca się sposób podejścia do pracy. W sektorze usługowym częściej związanym $\mathrm{z}$ pracownikami umysłowymi, ręczny transport materiałów wydaje się być pracą zbyt ciężką, czego nie można powiedzieć o sektorze produkcyjnym.

Podobne tendencje utrzymują się w krajach Unii Europejskiej, coraz częściej to dolegliwości mięśniowo-szkieletowe związane z wykonywaną praca są zgłaszane przez pracowników. Prawie co 4 pracownik w Europie skarży się na bóle kręgosłupa i mięśni $[7,8]$. 
Tab. 3. Rozklad wskazań (wedtug średnich) powodów dolegliwości uktadu mięśniowoszkieletowego występujących najczęściej w opinii respondentów wedlug sektora dzialalności

\begin{tabular}{|l|l|l|l|l|l|}
\hline \multicolumn{1}{|c|}{ ZMIENNA } & \multicolumn{5}{|c|}{ ŚREDNIA OCENA } \\
\cline { 2 - 6 } & $\begin{array}{l}\text { Przedsiębiorstwa } \\
\text { produkcyjne }\end{array}$ & $\begin{array}{l}\text { Przedsiębiorstwa } \\
\text { usługowe }\end{array}$ & $\begin{array}{l}\text { Przedsiębiorstwa } \\
\text { handlowe }\end{array}$ & $\begin{array}{l}\text { Przedsiębiorstwa } \\
\text { mieszane }\end{array}$ & Razem \\
\hline $\begin{array}{l}\text { Czynności często } \\
\text { powtarzające się }\end{array}$ & 3,241 & 3,100 & 2,750 & 3,093 & 3,120 \\
\hline $\begin{array}{l}\text { Nieprawidłowa } \\
\text { pozycja przy } \\
\text { pracy }\end{array}$ & 3,029 & 2,963 & 2,667 & 2,736 & 2,936 \\
\hline $\begin{array}{l}\text { Wymuszona przy } \\
\text { pozycja } \\
\text { pracy }\end{array}$ & 3,062 & 2,975 & 2,917 & 2,936 & 2,988 \\
\hline $\begin{array}{l}\text { Ręczny transport } \\
\text { materiałów }\end{array}$ & 2,656 & 2,980 & 2,750 & 2,550 & 2,834 \\
\hline $\begin{array}{l}\text { Nieergonomicznie } \\
\text { zaprojektowane i } \\
\text { wyposażone } \\
\text { stanowisko pracy }\end{array}$ & 2,527 & 2,358 & 2,389 & 2,143 & \\
\hline
\end{tabular}

Źódło: Opracowanie własne - wartości istotne statystycznie na poziomie $\alpha=0,05$

\section{Dzialania profilaktyczne i prewencja - podsumowanie}

Wypadki przy pracy oraz choroby zawodowe, które są następstwem nieodpowiednich warunków pracy niosą za sobą bardzo duże koszty. Jako pierwszy, analiz ekonomicznych dotyczących wpływu niewłaściwych warunków pracy dokonał w roku 1926 H. W. Heinrich [9]. Koszty związane z następstwami nieodpowiednich warunków pracy bądź zachowań pracowników ponoszą zarówno osoby fizyczne, jak i sektor publiczny. Urazy będące następstwem wypadków przy pracy zwiększają bowiem zapotrzebowanie na różnego rodzaju usługi. Do najważniejszych należy oczywiście usługa medyczna. Jak wiadomo ostatecznie koszty obciążają wszystkich podatników. Wypadki powodują istotne straty w gospodarce [10]. Według danych EU-OSHA (Europejskiej Agencji Bezpieczeństwa i Zdrowia w Pracy) oscylują one w granicy 2,6-4,0 PKB [11].

Według CIOP-PIB (Centralny Instytut Ochrony Pracy - Państwowy Instytut Badawczy) w Polsce koszty związane z niewłaściwymi warunkami pracy to około 3\% PKB [12]. Na ogólne koszty bezpieczeństwa składają się zarówno koszty związane z wypadkami jak i koszty profilaktyki oraz prewencji. Centralny Instytut Ochrony Pracy - Państwowy Instytut Badawczy, na początku lat dwutysięcznych opracował model kosztów bezpieczeństwa i higieny pracy. Podzielono wspomniane koszty na trzy kategorie. Pierwszą stanowiły koszty ubezpieczenia wypadkowego, 
drugą - koszty będące skutkiem wypadków przy pracy i chorób zawodowych, trzecią - koszty wynikające z pracy w warunkach szkodliwych i uciążliwych [13].

Oczywiście koszty wypadków przy pracy stanowią największy udział w ogólnych kosztach bezpieczeństwa pracy. Jednak główny ciężar ponoszonych strat z tytułu wypadków przy pracy ponosi przedsiębiorstwo. Oprócz sfery finansowej przedsiębiorstwo ponosi również stratę $\mathrm{w}$ aspekcie wizerunku firmy. Działania prewencyjne i profilaktyczne zagrożeń zdrowia i życia przede wszystkim leżą w gestii pracodawcy. Niestety praktyki pokazują, że przedsiębiorstwa nie chcą ponosić kosztów związanych z działaniami profilaktycznymi bądź prewencyjnymi, a jeśli już to jest to minimum niezbędnych kosztów, wymaganych aktualnymi przepisami prawa. Państwowa Inspekcja Pracy zwraca uwagę na niezaprzeczalny fakt, a mianowicie, że w Polsce główną przyczyną większości wypadków jest nieodpowiednie zachowanie pracowników, które wynika m.in. z braku dostatecznej wiedzy, która powinna pochodzić ze szkoleń bhp, jak również informacji dotyczących odpowiedniej i bezpiecznej organizacji pracy (szkolenia instruktażowe). Zazwyczaj wszelkie działania profilaktyczne i prewencyjne $\mathrm{w}$ przedsiębiorstwach są wspierane przez instytucje ubezpieczeniowe, społeczne, związkowe jak i samo państwo. Za główny stymulator zachęcający przedsiębiorstwa do dbania o warunki pracy, bezpieczeństwo pracowników w zakładach pracy uważa się system zróżnicowanych składek na ubezpieczenia wypadkowe, który funkcjonuje od wielu lat w większości krajów europejskich [14].

W ostatnich latach dość duży nacisk, wszelkie instytucje zajmujące się bezpieczeństwem i higieną pracy (EU-OSHA, CIOP-PIB, Instytut Medycyny Pracy w Łodzi, PIP) kładą na promowanie bezpiecznych zachowań wśród pracowników. Promocja ta przybiera różne formy - szkoleń , konferencji, warsztatów, konkursów, seminariów itp. Istnieją w Polsce przedsiębiorstwa (zwłaszcza średnie i duże), które samodzielnie podejmują próby prewencyjne i profilaktyczne upatrując w nich więcej wymiernych korzyści niż kosztów. Niestety w większości przedsiębiorstw „małej wielkości" z kolei wciąż pokutuje przeświadczenie, że wszelkie działania promujące bezpieczne zachowania, warunki pracy, działania profilaktyczne i prewencyjne to tylko zbędny koszt dla firmy. Jedną $\mathrm{z}$ metod działań prewencyjnych i profilaktycznych jest wdrażanie kompleksowo systemu zarządzania bhp, który może spełnić swoją rolę również w najmniejszych podmiotach gospodarczych. W uproszczony sposób można jego wdrażanie oprzeć przede wszystkim na cyklu Deminga, którego to celem jest ciągłe doskonalenie i poprawa warunków bezpieczeństwa pracy $\mathrm{w}$ przedsiębiorstwie. Jak pokazuje literatura przedmiotu, w przedsiębiorstwach, które wdrożyły system zarządzania bhp, zaobserwowano spadek liczby wypadków przy pracy, czyli firmy uzyskały wymierne korzyści działań prewencyjnych i profilaktycznych [15]. 
Wspomniane już wcześniej stymulatory ekonomiczne są najbardziej rozpowszechnionymi w poszczególnych krajach europejskich. Spośród nich najbardziej skutecznymi i rozpowszechnionymi okazał się tzw. „motywacyjny system ubezpieczeń" oparty na wspomnianej już wcześniej zróżnicowanej składce na ubezpieczenie wypadkowe. Zasada działania tego systemu w wielkim skrócie brzmi następująco - „dbasz o bezpieczne miejsce pracy to płacisz mało, nie dbasz to płacisz dużo". Niestety system ten obnażył wiele wad. Pracodawcy, by uniknąć większych składek, zaczęli „zamiatać pod dywan” zdarzenia wypadkowe, które miały miejsce $\mathrm{w}$ ich zakładach, co powoduje niedoszacowanie w liczbie rzeczywistych zdarzeń wypadkowych i wypadków przy pracy. W nowoczesnych przedsiębiorstwach kierownictwo dba o swój kapitał jakim jest niewątpliwie pracownik. Pracodawcy coraz częściej korzystają z narzędzi motywujących do bezpiecznej i bezwypadkowej pracy w postaci premii, nagród, awansów. Kara nie stanowi już efektywnego narzędzia, które motywuje pracowników do bezpiecznej pracy $\mathrm{w}$ przedsiębiorstwie [16]. Należy zwrócić uwagę na fakt, iż najmniejsze podmioty gospodarcze bardzo często pozbawione są odpowiedniej dbałości o bezpieczne warunki pracy w aspekcie zdrowia i życia pracowników, a przyczyny wypadków przy pracy oraz dolegliwości zdrowotne związane z jej wykonywaniem mogłyby być minimalizowane a nawet likwidowane.

\section{Bibliografia}

[1.] Raport z badania opinii, Bezpieczeństwo pracy w Polsce 2014 r., Koalicja Bezpieczni w Pracy, www.bezpieczniwpracy.pl

[2.] Giedrojć R., Sprawozdanie z działalności Państwowej Inspekcji Pracy w 2015 r., Wyd. PIP, Warszawa 2016;

[3.] Paluch R., Studenski R., Okolice stanów średnich, w: ATEST 12/2000;

[4.] Europejska Agencja Bezpieczeństwa i Zdrowia w Pracy, Kontekst $i$ środki dotyczace bezpieczeństwa $i$ higieny pracy stosowane $w$ mikroprzedsiębiorstwach $i$ matych przedsiębiorstwach w UE - projekt SESAME, streszczenie Europejskiego Obserwatorium Ryzyka, www.osha.europa.eu ;

[5.] Raport z badania opinii, Bezpieczeństwo pracy w Polsce 2016 r., Koalicja Bezpieczni w Pracy, www.bezpieczniwpracy.pl;

[6.] Art. 3 ust. 5 ustawy z dn. 30.10.2002 r., Dz. U. z 2009 r., Nr 167, poz. 1322, z późn. zm.;

[7.] Europejska Agencja Bezpieczeństwa i Zdrowia w Pracy, Wyzwanie związane z BHP $w$ mikroprzedsiębiorstwach $i$ matych przedsiębiorstwach: co można zrobić?, https://osha.europa.eu/pl/about-eu-osha/press-room/challenge-safety-and-healthmicro-and-small-enterprises-what-can-be-done, z dnia 21.06.2016;

[8.] Petreanu V., Seracin A. M., Iordache R., Musculoskeletal disorders in visual display unit (VDU) tasks, National Research - Development for Health and Safety, Romania, 2016;

[9.] Heinrich H. W., Industrial accidents prevention, Mc-Graw Hill, New York 1941; 
[10.] Rzepecki J., Ekonomiczne aspekty kształtowania warunków pracy, w: Bezpieczeństwo Pracy 12/2007, Wyd. CIOP-PIB, Warszawa 2007;

[11.] Europejska Agencja Bezpieczeństwa i Zdrowia w Pracy, Oszacowanie kosztów wypadków przy pracy i chorób zawodowych, Luksemburg 2013, http//osha.europa.eu//;

[12.] Centralny Instytut Ochrony Pracy - Państwowy Instytut Badawczy, Ekonomiczne aspekty kształtowania warunków pracy, Warszawa 2014;

[13.] Rzepecki J., BHP w przedsiębiorstwie - model analizy kosztów i korzyści, w: Bezpieczeństwo Pracy - Nauka i Praktyka, Nr 2/2002, Wyd. CIOP-PIB, Warszawa 2002;

[14.] Pawłowska Z., Rzepecki J., Metody obliczania kosztów wypadków przy pracy, w: Bezpieczeństwo Pracy - Nauka i Praktyka, Nr 6/1998;

[15.] Koradecka D., Nowa strategia Unii Europejskiej w kierunku bezpieczeństwa i higieny pracy na lata 2007-2012, w: Bezpieczeństwo Pracy - Nauka i Praktyka, Nr 2/2007;

[16.] Sekuła Z., Motywowanie do pracy. Teorie i instrumenty, Wyd. PWE, Warszawa 2008;

\title{
CAUSES OF ACCIDENTS AT WORK AND IDENTIFICATION OF HEALTH PROBLEMS RELATED TO PROFESSIONAL WORK IN THE OPINION OF EMPLOYEES OF POLISH "SMALL-SIZED" ENTERPRISES
}

\begin{abstract}
The article presents the results of research conducted among employees of the smallest business entities in Poland. The research concerned the causes of accidents at work, which take place in the surveyed business entities and health related problems with the work performed, which are identified by the respondents. The results show trends in the subject taken and indicate those areas that need improvement in terms of security and to protect the health of employees of small-sized enterprises.
\end{abstract}

Key words: work safety, ergonomics, health protection, prevention, "small-sized" enterprises.

Data przestania publikacji do Redakcji: 11.06.2018

Data akceptacji publikacji przez Redakcje: 27.07.2018 